\title{
Influence of Salinity and Osmotic Stress on Germination Process in an Old Sicilian Landrace and a Modern Cultivar of Triticum Durum Desf.
}

\author{
C. Maucieri ${ }^{1}$, C. CARuso ${ }^{1,2}$, S. Bona ${ }^{1}$, M. Borin ${ }^{1}$, A. C. Barbera ${ }^{2,3 *}$ and V. CAVAllaro ${ }^{3}$ \\ ${ }^{1}$ Department of Agronomy, Food, Natural Resources, Animals and Environment - DAFNAE, \\ University of Padua, Agripolis Campus, Viale dell'Università 16-35020 Legnaro (PD), Italy \\ ${ }^{2}$ Department of Agriculture, Food and Environment (Di3A), University of Catania, \\ Via Valdisavoia 5, 95123 Catania (CT), Italy \\ ${ }^{3}$ Trees and Timber Institute (IVALSA), National Research Council (CNR), \\ Via Paolo Gaifami 18, 95121 Catania (CT), Italy \\ (Received 4 April 2017; Accepted 11 October 2017; \\ Communicated by A. Goyal)
}

\begin{abstract}
In many world regions, osmotic and salt stresses are becoming the primary environmental conditions limiting successful establishment of crops. The old durum wheat landraces may provide a source of genes useful to enhance crop resilience to the abiotic stresses of dryland areas or foreseen as a result of climate change. With this in mind, in order to determine the effects of salt and osmotic stresses on durum wheat germination, an old Sicilian durum wheat landrace "Timilia" and a relatively recent cultivar "Mongibello" were investigated at various iso-osmotic solutions of $\mathrm{NaCl}$ and mannitol at osmotic potentials of: 0 control, $-0.125,-0.250,-0.500$ and $-0.750 \mathrm{MPa}$.

Under stress conditions, different germination and early growth behavior was observed in the two durum wheat genotypes. Timilia presented almost stable germination even at the highest osmotic stresses $(96.7 \%$ and $88.3 \%$ seed germination at 0 and $-0.750 \mathrm{MPa}$, respectively) showing a higher capacity of seed imbibition than Mongibello. The latter thus showed a higher sensitivity than the old landrace to the studied stresses. The variability ascertained in the response to salinity stress indicate that Timilia could be a source of interesting genes for breeding programs.
\end{abstract}

Keywords: durum wheat, seed germination, salinity stress, osmotic stress, old and modern durum wheat genotypes

\section{Introduction}

In many semiarid regions salinity stress is one of the most limiting environmental conditions restricting successful crop establishment (Paranychianakis and Chartzoulakis 2005; Royo and Abió 2003). Moreover, in these areas, several low quality water sources (olive mill wastewaters, urban treated wastewaters, etc.) may enhance the water and nutrients availability at low cost (Borin et al. 2013; Campi et al. 2014, 2015). In Mediterranean 
regions with serious water and soil organic matter deficiencies, the reuse of these wastewaters could be doubly useful (Barbera et al. 2013, 2014), but due to their composition, especially salts content, they can negatively influence seed germination processes (Almansouri et al. 2001), crop establishment and soil fertility (Mavi et al. 2012).

Salinity can affect seed germination either by increasing osmotic potential, which reduces water uptake, or by the toxic effects of sodium and chloride ions on seed metabolism.

Although, as Almansouri et al. (2001) report, there is no clear evidence that salt resistance during germination implies that plants will show similar resistance during their growth, low seed germination determines sparser plant stands with a negative impact on crop yield. As reported in Bağci et al. (2007) the soil reclamation approach, as a solution to a salinity problem, is a quite expensive strategy, and in many cases, it is difficult to obtain good results especially where irrigation water is saline, the water table high and drainage poor. Therefore, when water salinity is not excessively severe, the cultivation of tolerant species and selected varieties is a practical agronomic solution. In this context, saving and evaluating the genetic variability of old genotypes is an important feature. Although salt tolerant and/or resistant varieties can be selected within crop species, as reported in Tanksley and McCouch (1997), an intensive selection would result in a progressive narrowing of the genetic base of selected populations. Cultivation of genotypes with a narrow genetic base entails a risk since it could lead to severe crop losses due to mutations in pest populations or changes in environmental conditions that the cultivar could not cope with (Reif et al. 2005). Landraces are well adapted to their specific environment, but are generally unable to satisfy the requirements of intensive agricultural systems or the quality traits demanded by food industries (Piergiovanni 2013). However, since an improved variety might also be unable to give high yields in marginal conditions (characterized by abiotic stresses such as osmotic and saline ones), using landraces as possible crops could be a valuable alternative to obtain reasonable yields in these environments. Furthermore, in the last years, both farmers and consumers have showed an increasing interest in wheat landraces for bread and pasta production. Piergiovanni (2013) reported that a farmer's consortium in northwestern Italy is attempting the re-introduction of Italian bread wheat landraces in some cereal agroecosystems. This author also indicated that the increasing consumers' request for new wheat derivative specialties, organic food and the possible widening of marketing opportunities is giving new chances for survival to both landraces and old varieties and is providing a way to safeguard these valuable genetic resources. In addition, Naspetti and Bodini (2008) reported that many consumers are interested in local products because of the perceived benefits of freshness, better taste and higher quality. Gallo et al. (2010), comparing old and improved Sicilian varieties, reported that the different chemical and rheological properties of the raw material, grain and semolina, were reflected in the derived breads. Lastly, Dinelli et al. (2009, 2013) found a significantly higher presence of phenolic compounds in old durum wheat genotypes as compared to modern cultivars.

In addition to the quality enhancement of wheat grain products, the old varieties or landraces give a higher straw production than new semi-dwarf wheat cultivars. This as- 
pect that reduces the harvest index, in marginal areas could be a resource for non-intensive animal husbandry based on native species to develop a low input and environmentally friendly agronomic system.

An interesting old spring durum wheat genotype suitable for Sicilian marginal land is "Timilia" (Triticum durum Desf. var. aff. Koern), cultivated in many Mediterranean countries in the first half of the last century. It is a drought resistant landrace known for its good yield potential. In Sicily, this landrace is nowadays grown on hundreds of hectares, but the cultivated surface is progressively incrementing because of rising consumer interest in the pasta and in the characteristic breads produced with its flour (Palumbo et al. 2008). To our knowledge, no data are available on the effects of salt and osmotic stress during germination of the durum wheat landrace Timilia.

With this in mind, the aim of this study was to investigate the effects of osmotic and salinity stresses on seed germination and plantlet growth of two durum wheat genotypes, an old one "Timilia" and the more recently selected "Mongibello".

\section{Materials and methods}

Twelve-month-old seeds of two Triticum durum Desf. genotypes, Timilia (SG1) and Mongibello, were chosen for the experiment. For each genotype, seeds of uniform size were hand-selected, and used for the imbibition and germination tests. The two seed lots had a 1,000 seeds weight of $32.8 \mathrm{~g}$ and $55.0 \mathrm{~g}$ for Timilia and Mongibello, respectively. Seeds were surface-sterilized in a $1 \%$ sodium hypochlorite solution, rinsed in sterile distilled water and quickly dried before the experiment. The studied treatments are listed in Table S1*.

Salinity stress was induced in the solutions adding sodium chloride $(\mathrm{NaCl})$ or mannitol each at concentrations able to give the same potentials of the other osmoticum. Osmotic potential in $\mathrm{NaCl}$ solutions was confirmed using an automatic cryoscopic osmometer (Gonotec Osmomat 030 model, Berlin, Germany). Mannitol solutions were prepared, according to the water potential to be induced, as described by Machado Neto et al. (2004).

\section{Seeds water uptake}

For each treatment, seed moisture at 2, 4, 6, 16, 18, 20, 48, 60, 72 and 96 h of imbibition was measured in Mongibello. Due to the faster water absorption and germination in Timilia, seed moisture was detected at the same intervals up to 48 hours. For this purpose, three replications of 10 seeds each were placed in Petri dishes with $10 \mathrm{ml}$ of tested solution. After the start of imbibition, seeds were removed at each measuring time, drained and blotted with absorbent paper, weighed and replaced in the Petri dishes. Seed moisture was determined as:

$$
\text { [(total weight }- \text { initial weight }) / \text { initial weight }] \times 100 \text {. }
$$

\section{Germination test}

*Further details about the Electronic Supplementary Material (ESM) can be found at the end of the article. 
For the germination tests, 25 seeds for replicate were placed in a Petri dish $(9 \mathrm{~cm})$, on a single piece of Whatman ${ }^{\circledR}$ Filter Paper \#3. The paper was moistened with $8 \mathrm{ml}$ of the studied solutions and replenished as needed. Each treatment was replicated in triplicate. Dishes were hermetically sealed with Parafilm ${ }^{\circledR}$ to prevent evaporation and then incubated in the dark at $25^{\circ} \mathrm{C}$. Seeds were scored as germinated when a radicle protrusion of approximately $2 \mathrm{~mm}$ was observed. Germination was assessed at $24 \mathrm{~h}$ intervals until no further germination was observed for three consecutive days.

Mean germination time (MGT) was also calculated as follows:

$$
\mathrm{MTG}=\sum(H n) / \sum n
$$

where $n$ is the number of seeds that germinate at the hour $(H), H$ the number of hours counted from the beginning of the test (Ellis and Roberts 1981).

\section{Radicle and plumule measures}

Radicle and plumule measurements were also determined for each experimental treatment. For each Petri dish, five germinated seeds were randomly chosen 3 days after the beginning of germination, and the radicle and plumule were excised and measured. Radicle and plumule length, fresh and dry weight (by drying them in a thermo-ventilated oven at $65{ }^{\circ} \mathrm{C}$ until constant weight was reached), were determined.

\section{Statistical analysis}

All the data were analyzed using ANOVA and comparisons between means were made using the Fisher LSD test. The relation between germination data and seedling parameters was addressed through Pearson correlation. Statistical analysis of data was performed using SigmaPlot 12.0 (Systat Software Inc. San Jose, California, USA) and XLSTAT 2015 (Addinsoft USA, New York, USA).

\section{Results}

\section{Water imbibition}

Considering all the studied factors, Timilia genotype always showed a higher imbibition rate than Mongibello $(p<0.001)$ (Fig. S1). When a separate statistical analysis was performed for each genotype no significant differences in water uptake were detected in relation to the osmotic agents. On average of the osmotic agents, no differences were observed in relation to the different osmotic potentials up to eighteen hours in Mongibello (Fig. S2a) and six hours in Timilia (Fig. S2b) from the beginning of imbibition. 
As concerns Mongibello, thereafter, a progressive increase occurred in seed moisture content up to the beginning of germination ( $96 \mathrm{~h}$ in most treatments). In the same cultivar, the seed moisture rate over time differed in relation to the osmotic potential of the imbibition solutions, the only exception being the germination at $-0.125 \mathrm{MPa}$ that did not significantly differ from the control (germination at $0 \mathrm{MPa}$ ). The differences were more marked in the last two measurements (Fig. S2a). At 72 hours the decreases in water absorption as compared to the control $(100 \%)$ were $-3.2 \%$ (at $-0.125 \mathrm{MPa}),-8.3 \%(-0.250$ $\mathrm{MPa}),-15.9 \%(-0.500 \mathrm{MPa}),-21.6 \%(-0.750 \mathrm{MPa})$.

In Timilia (Fig. S2b) the differences in seed water uptake determined by the different osmotic solutions became evident soon after the first six hours from the beginning of imbibition. Even here, the rate of water absorption over time was reduced by the increase in the osmotic potential of the germination solutions (Fig. S2b). Among the tested potentials, the highest one $(-0.750 \mathrm{MPa})$ induced the lowest water uptake as compared to the other germination solutions. At 48 hours from imbibition beginning, when these differences were more evident, the control seed moisture content (due to water absorption) increased by $76 \%$ whereas the seed moistures determined by the osmotic solutions ranged from $59 \%(-0.750 \mathrm{MPa})$ to $67 \%(-0.125 \mathrm{MPa})$. At the highest water potential $(-0.750$ $\mathrm{MPa}$ ), after 48 hours of imbibition, relative moisture content of Timilia seeds was higher than that recorded in Mongibello ones (50.6\%) and close to that observed in the same genotype at $0 \mathrm{MPa}(65 \%)$ at 96 hours imbibition (Fig. S2a and Fig. S2b).

\section{Germination test}

Final seed germination of the two durum wheat genotypes was differently affected by salinity and water stress. Timilia, which reached $96.7 \%$ of germinated seeds in the absence of osmotic stress, showed no significant difference in germination when incubated at the various iso-osmotic solutions of $\mathrm{NaCl}$ and mannitol, with an average germination at the highest osmotic pressure $(-0.750 \mathrm{MPa})$ reduced by only $8.4 \%$ as compared to the control (Fig. S3a). Instead, osmotic pressure and solutes significantly influenced Mongibello germination, where the highest germination rate $(90.0 \%)$ was observed in the control. Significantly lower germination was observed starting at $-0.500 \mathrm{MPa}$ in $\mathrm{NaCl}$ and at $-0.750 \mathrm{MPa}$ in mannitol germination solutions. The lowest germination $(21.7 \%)$ was recorded at $-0.750 \mathrm{MPa}$ in $\mathrm{NaCl}$ (Fig. S3b).

MGT was significantly influenced by all the studied factors (Table S2) but not by their interactions. Mongibello showed a MGT (67 hours) almost double that of Timilia (34 hours). In the average of the studied genotypes and osmotic potentials, germination in $\mathrm{NaCl}$ was delayed (54 hours) as compared to that in mannitol (46.7 hours). Finally, whatever the osmoticum and the genotype, significant MGT increases were determined only at the two highest levels of osmotic potential ( +8 hours at $-0.500 \mathrm{MPa}$ and +11 hours at $-0.750 \mathrm{MPa}$; control $=45.4$ hours). 


\section{Radicle measurements}

Genotype, osmotic agent, germination medium potential and their interaction significantly influenced root characteristics. Untreated seeds of the cultivar Mongibello showed significantly higher root length and dry weight $(7.76 \pm 0.67 \mathrm{~cm}$ and $5.17 \pm 0.51 \mathrm{mg}$, respectively) than Timilia ( $5.14 \pm 0.49 \mathrm{~cm}$ and $3.23 \pm 0.35 \mathrm{mg}$, respectively).

Different behavior was observed in relation to the osmotic agent used. As concerns germination in mannitol, no significant decline in root dry weight and length was observed up to $-0.500 \mathrm{MPa}$ in either genotype. At $-0.750 \mathrm{MPa}$, Mongibello showed a decrease of $-52 \%$ in root weight (Fig. S4a) and $-58 \%$ in root length (Fig. S4b), whereas Timilia of $-23 \%$ and $-39 \%$. In both genotypes, germination in $\mathrm{NaCl}$ induced more detrimental effects on measured root characteristics than those observed in mannitol. However, they were less consistent in Timilia. A rapid decline in root dry weight and length was already observed in Mongibello at the lowest osmotic potential, whereas no differences occurred in Timilia up to $-0.500 \mathrm{MPa}$ (Fig. S4a and Fig. S4b). Germination in the $\mathrm{NaCl}$ solution at $-0.750 \mathrm{MPa}$, as compared to that in distilled water caused a decrease in root weight and length, greater for Mongibello ( $-76 \%$ and $-78 \%$, respectively) than for Timilia $(-35 \%$ and $-48 \%)$.

\section{Plumule measurements}

In the average of the osmotic agents and stress levels, plumule dry weight in Timilia (3.35 $\mathrm{mg}$ ) was significantly $(p<0.01)$ lower than in Mongibello $(4.05 \mathrm{mg})$. On the average of the other factors, germination in $\mathrm{NaCl}$ determined a significant $(p<0.01)$ reduction in plumule dry weight $(3.37 \mathrm{mg})$ as compared to mannitol $(4.14 \mathrm{mg})$. Plotting the decreasing rate (germination at $0 \mathrm{MPa}=100$ ) of plumule dry weight against osmotic potentials, and testing the differences between slopes (b coefficients) of the linear regressions by the Student $t$-test, the behavior of the two genotypes within each osmotic potential in mannitol or in $\mathrm{NaCl}$ was compared. A negative linear relation between plumule dry weight and osmotic potential was obtained for both genotypes $(p<0.05$ for Mongibello and $p<0.01$ for Timilia), with a lower decreasing rate for Timilia (angular coefficient $=-4.12$ ) as compared to Mongibello (angular coefficient $=-7.47$ ) (Fig. S5).

A reduction in plumule elongation starting from the lowest osmotic potentials was observed in both Mongibello and Timilia (Fig. S6).

In Timilia, however, the decreasing rate (slope coefficient of the linear regression $=15.6$ ) of epicotyl length in mannitol was significantly slower than in $\mathrm{NaCl}(21.9)$ and that observed in both osmotica in the other genotype (22.8 on average of the two osmotica).

\section{Correlation between germination and seedling biometrics characteristics}

In Mongibello all the studied parameters, except length/dry weight roots ratio, Mongibello showed positive correlations with the germination rate. In Timilia, only a positive 
correlation between germination rate and plumule elongation was observed. The root length in both genotypes was positively correlated with all the parameters with the only exception of length/dry weight roots ratio of Mongibello cultivar (Table S3).

\section{Discussion}

As reported by Almansouri et al. (2001) saline and water stresses can reduce seeds germination by: i) limiting water absorption, ii) affecting the mobilization of stored reserves or iii) affecting the proteins structural organization or synthesis in germinating embryos. Our results showed that the two durum wheat genotypes are characterized by different germination responses to osmotic and salinity stress. The landrace genotype, Timilia, showed a higher capacity of water absorption at the beginning of the germination process and an almost stable germination rate even at the highest osmotic stresses induced by both solutes. In Mongibello, the lower water absorption rate was associated to a higher sensitivity to osmotic stresses and $\mathrm{NaCl}$ toxicity, as confirmed by the significantly lower germination rate at -0.500 and $-0.750 \mathrm{MPa}$ in presence of $\mathrm{NaCl}$.

Moreover, water salinity can influence seeds germination process by the toxic ions intake, which may alter some enzymatic and hormonal reactions (Kaveh et al. 2011) determining a slower or lower germination rate (Gholamin and Khayatnezhad 2013), with a possible additional effect of the osmotic salt stress component. Osmotic and ionic effects of salt stress during seeds germination may be distinguished by comparing $\mathrm{NaCl}$ treatment with an inert osmotic substance like mannitol, as any germination inhibition by a given salt concentration which goes beyond that caused by iso-osmotic solutions induced by inert solutes should be due to ionic effects (Almansouri et al. 2001). In this study, the delay in seeds germination induced by osmotic stress was influenced by the osmotic agent and the wheat genotypes, in agreement with Almansouri et al. (2001). However, mannitol exerted a lower toxic effect than $\mathrm{NaCl}$ in Mongibello. Mannitol can penetrate the seeds decreasing their internal osmotic potential and so allowing water uptake (Thomas et al. 1995), even under high osmotic stresses of the germination solution. In our experiments, Mongibello seeds germination was influenced by both ionic (at all concentrations) and osmotic (only at the highest doses) stress. Timilia seed germination was not affected by any of the induced stresses during germination whatever the osmoticum. Even in $\mathrm{NaCl}$ solutions, the ions may penetrate the cell wall determining a decrease in the internal osmotic potential, as suggested by Almansouri et al. (2001), leading to an increase in water uptake and initiation of germination processes. However, the differences in the germination behavior highlighted in the two studied genotypes, indicate that this mechanism must be associated to a greater tolerance to the $\mathrm{NaCl}$ ion toxic effects in the old landrace Timilia, as total germination was not damaged even at the highest studied salinity stresses. Another important feature associated to the salinity and osmotic stress tolerance of this genotype may be its capability to rapidly absorb enough water to begin the carbohydrate demolition processes leading to germination.

It is a matter of debate if salinity resistance during germination implies that mature plants will show similar resistance. Indeed, several studies demonstrated that the evolu- 
tion of salinity resistance at various phenological stages is different among cultivars of a given species (Lutts et al. 1995; Rawson et al. 1988). Since however germination and first seedling growth in response to different salinity levels are necessary prerequisites for crop establishment, their evaluation may be helpful to reduce the time spending in breeding open field trials. The cellular elongation process and carbohydrates wall synthesis were very susceptible to water deficit (Wenkert et al. 1978). After germination, plants have to develop their structures (roots and shoots). Root and plumule growth could therefore be important parameters to evaluate genotypes tolerance to salinity stress soon after germination. Mongibello radicle growth (weight and length) in the absence of osmotic/ saline stresses was greater than that of Timilia. In mannitol, the two genotypes showed a similar behavior, with no visible reductions in root growth (weight and length), till -0.500 $\mathrm{MPa}$ and a rapid decline thereafter. $\mathrm{NaCl}$ was the most detrimental solute for both genotypes root growth. However, radicle growth of the cultivar Mongibello was significantly reduced even at moderate stress conditions $(-0.125 \mathrm{MPa})$ as compared to Timilia.

As concerns plumule growth, germination in $\mathrm{NaCl}$ determined a significant reduction in plumule dry weight in both genotypes. Regardless of the osmotic compounds and genotypes, a constant decrease in plumule weight and elongation was observed starting from the lowest water osmotic potential. Plumule growth exhibited a higher sensitivity than radicle growth. In Timilia, however, the decreasing rate (slope coefficient) of plumule length in mannitol was significantly slower than in $\mathrm{NaCl}$ and in Mongibello in both osmotica, showing a genotype specific response for this character as previously reported by Muhammad and Hussain (2012) and Sourour et al. (2014). Even if further field investigations at the whole plant growth stage may be useful to explore the resistance of these genotypes to salinity, this research confirmed that the first stages of plantlet development (i.e. root and plumule growth) are important parameters to be considered. In fact, due to their greater sensitivity to stress as compared to germination, they must be taken in consideration to forecast plantlets behavior under abiotic stresses (drought and salinity) in field conditions (Cavallaro et al. 2016).

In conclusion, the genetic variability in durum wheat should be also improved through the evaluation and conservation of its old genotypes. The two genotypes in this study showed different behavior in response to osmotic/saline stresses. The older landrace, Timilia, was able to bear even very high salt stresses, especially during germination. Mongibello, the modern cultivar, showed a greater sensitivity to ionic and osmotic stress. From a genetic point of view, the variability ascertained in the response to salinity stress seems to indicate that Timilia could be a source of interesting genes for breeding programs. Further studies need to be done in order to exploit and save the genetic potential of other old wheat genotypes. 


\section{References}

Almansouri, M., Kinet, J.M., Lutts, S. 2001. Effect of salt and osmotic stresses on germination in durum wheat (Triticum durum Desf.). Plant Soil 231:243-254.

Bağci, S.A., Ekiz, H., Yilmaz, A. 2007. Salt tolerance of sixteen wheat genotypes during seedling growth. Turk. J. Agric. For. 31:363-372

Barbera, A.C., Maucieri, C., Cavallaro, V., Ioppolo, A., Spagna, G. 2013. Effects of spreading olive mill wastewater on soil properties and crops, a review. Agr. Water Manage. 119:43-53.

Barbera, A.C., Maucieri, C., Ioppolo, A., Milani, M., Cavallaro, V. 2014. Effects of olive mill wastewater physico-chemical treatments on polyphenol abatement and Italian ryegrass (Lolium multiflorum Lam.) germinability. Water Res. 52:275-281.

Borin, M., Barbera, A.C., Milani, M., Molari, G., Zimbone, S.M., Toscano, A. 2013. Biomass production and $\mathrm{N}$ balance of giant reed (Arundo donax L.) under high water and $\mathrm{N}$ input in Mediterranean environments. Eur. J. Agron. 51:117-119.

Campi, P., Navarro, A., Palumbo, A.D., Mastrangelo, M., Lonigro, A., Mastrorilli, M. 2015. Bioenergy productivity of sugar beet irrigated with reclaimed wastewaters. Ital. J. Agron. 10:155-159.

Campi, P., Navarro, A., Palumbo, A.D., Solimando, M., Lonigro, A., Mastrorilli, M. 2014. Productivity of energy sorghum irrigated with reclaimed wastewaters. Ital. J. Agron. 9:115-119.

Cavallaro, V., Barbera, A.C., Maucieri, C., Gimma, G., Scalisi, C., Patane, C. 2016. Evaluation of variability to drought and saline stress through the germination of different ecotypes of carob (Ceratonia siliqua L.) using a hydrotime model. Ecol. Eng. 95: 557-566.

Dinelli, G., Marotti, I., Di Silvestro, R., Bosi, S., Bregola, V., Accorsi, M., Di Loreto, A., Benedettelli, S., Ghiselli, L., Catizone, P. 2013. Agronomic, nutritional and nutraceutical aspects of durum wheat (Triticum durum Desf.) cultivars under low input agricultural management. Ital. J. Agron. 8:85-93.

Dinelli, G., Segua-Carretero, A., Di Silvestro, R., Marotti, I., Fu, S., Benedettelli, S., Ghiselli, L., FernandezGutierrez, A. 2009. Determination of phenolic compounds in modern and old varieties of durum wheat using liquid chromatography coupled with time-of-flight mass spectrometry. J. Chromatogr. A 1216:72297240 .

Ellis, R.H., Roberts, E.H. 1981. The quantification of ageing and survival in orthodox seeds. Seed Sci. Technol. (Netherlands).

Gallo, G., Bianco, M.L., Bognanni, R., Saimbene, G., Orlando, A., Grillo, O., Saccone, R., Venora, G. 2010. Durum wheat bread: Old Sicilian varieties and improved ones. J. Agric. Sci. Technol. 4(4): 10-17.

Gholamin, R., Khayatnezhad, M. 2013. The effects of water and salt stresses on germination in two bread wheat genotypes. Afr. J. Biotechnol. 10:17789-17792.

Kaveh, H., Nemati, H., Farsi, M., Jartoodeh, S.V. 2011. How salinity affect germination and emergence of tomato lines. J. Biodivers. Environ. Sci. 5:159-163.

Lutts, S., Kinet, J.M., Bouharmont, J. 1995. Changes in plant response to $\mathrm{NaCl}$ during development of rice (Oryza sativa L.) varieties differing in salinity resistance. J. Exp. Bot. 46(12):1843-1852.

Machado Neto, N.B., Saturnino, S.M., Bomfim, D.C., Custódio, C.C. 2004. Water stress induced by mannitol and sodium chloride in soybean cultivars. Braz. Arch. Biol. Techn. 47(4):521-529.

Mavi, M.S., Marschner, P., Chittleborough, D.J., Cox, J.W., Sanderman, J. 2012. Salinity and sodicity affect soil respiration and dissolved organic matter dynamics differentially in soils varying in texture. Soil Biol. Biochem. 45:8-13.

Muhammad, Z., Hussain, F. 2012. Effect of $\mathrm{NaCl}$ salinity on the germination and seedling growth of seven wheat genotypes. Pakistan J. Bot. 44:1845-1850.

Naspetti, S., Bodini, A. 2008. Consumer perception of local and organic products: Substitution or complementary goods?. Int. J. Interdiscip. Soc. Sci. 3:111-122.

Palumbo, M., Blangiforti, S., Cambrea, M., Gallo, G., Licciardello, S., Spina, A. 2008. Sicilian durum wheat landraces for production of traditional breads. In: Proceedings of the International Durum Wheat Symposium "From seed to pasta: the durum wheat chain", Bologna 2008:132.

Paranychianakis, N.V., Chartzoulakis, K.S. 2005. Irrigation of Mediterranean crops with saline water: from physiology to management practices. Agr. Ecosyst. Environ. 106:171-187. 
Piergiovanni, A.R. 2013. Evaluation of genetic variation and grain quality of old bread wheat varieties introduced in north-western Italian environments. Genet. Resour. Crop Ev. 60:325-333.

Rawson, H.M., Richards, R.A., Munns, R. 1988. An examination of selection criteria for salt tolerance in wheat, barley and triticale genotypes. Crop Pasture Sci. 39(5):59-772.

Reif, J.C., Zhang, P., Dreisigacker, S., Warburton, M.L., van Ginkel, M., Hoisington, D., Bohn, M., Melchinger, A.E. 2005. Wheat genetic diversity trends during domestication and breeding. Theor. Appl. Genet. 110:859864.

Royo, A., Abió, D. 2003. Salt tolerance in durum wheat cultivars. Span. J. Agric. Res. 1(3):27-35.

Sourour, A., Neila, R., Zoubeir, C., Saddreddine, B., Feker, K., Themir, B., Mayada, M., Mongi, B.Y. 2014. Effect of salt stress (sodium chloride) on germination and seedling growth of durum wheat (Triticum durum Desf.) genotypes. Int. J. Biodivers. Conserv. 6:320-325.

Tanksley, S.D., McCouch, S.R. 1997. Seed banks and molecular maps: unlocking genetic potential from the wild. Science 277:1063-1066.

Thomas, J.C., Sepahi, M., Arendall, B., Bohnert, H.J. 1995. Enhancement of seed germination in high salinity by engineering mannitol expression in Arabidopsis thaliana. Plant Cell Environ. 18:801-806.

Wenkert, W., Lemon, E.R., Sinclair, T.R. 1978. Leaf elongation and turgor pressure in field-grown soybean. Agron. J. 70(5):761-764.

\section{Electronic Supplementary Material (ESM)}

Electronic Supplementary Material (ESM) associated with this article can be found at the website of CRC at http://www.akademiai.com/content/120427/

Electronic Supplementary Table S1. Osmotic pressure and agents in the germination solutions

Electronic Supplementary Table S2. Mean germination time (hours \pm SD)

Electronic Supplementary Table S3. Correlation between germination and biometrics characteristics

Electronic Supplementary Figure S1. Time course of water imbibition in Mongibello and Timilia in the average of studied factors. Different letters indicate significant differences $(p<0.05)$ according to the Fisher's LSD test

Electronic Supplementary Figure S2. Time course of imbibition in Mongibello (upper graph) and Timilia (lower graph) in relation to the water potentials of the imbibition solutions. LSD at $p<0.05$ was calculated according to the Fisher's LSD test

Electronic Supplementary Figure S3. Final germination percentages in relation to different osmotic solutions in Timilia (upper graph) and in Mongibello (lower graph). Different letters indicate significant differences $(p<0.05)$ according to the Fisher's LSD test

Electronic Supplementary Figure S4. Treatments effect on root length (on the left) and dry weight (on the right). Vertical bars indicate the confidence limits $(p<0.05)$ at each osmotic potential

Electronic Supplementary Figure S5. Linear regression between osmotic potential and plumule dry weight

Electronic Supplementary Figure S6. Plumule length decrease as affected by the different potentials of the germination solution 